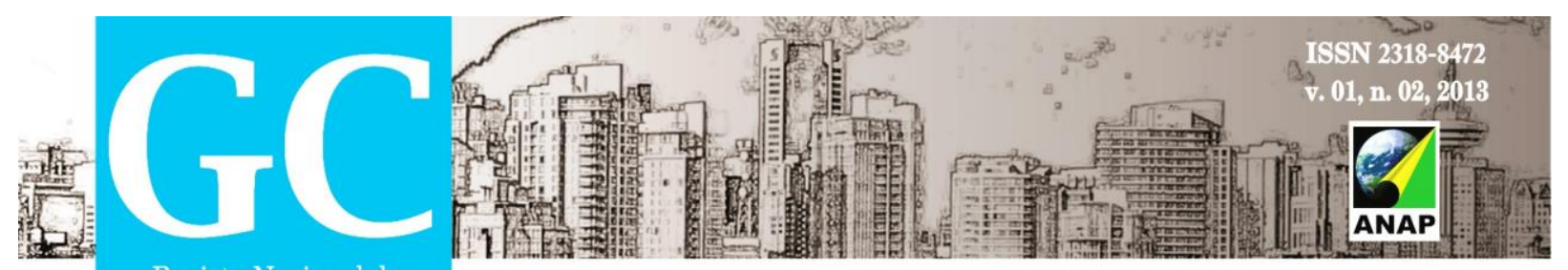

Revista Nacional de

Gerenciamento de Cidades

\title{
ZONAS ESPECIAIS DE INTERESSE SOCIAL (ZEIS): APLICAÇÃO NO PLANO DIRETOR DE SÃO PAULO - 0 CASO DA OPERAÇÃO URBANA ÁGUA ESPRAIADA
}

\section{Fernanda Amorim Militelli ${ }^{1}$}

RESUMO: A evolução do Direito Urbanístico, a partir da promulgação da Constituição de 1988, e Lei Federal n 10.257/01 que institui o Estatuto da Cidade, definiu instrumentos urbanísticos, que podem ser utilizados a partir dos Planos Diretores, a fim de garantir o principio da função social da propriedade e da cidade. Do rol de instrumentos parametrizados pelo Estatuto da Cidade, a Zona Especial de Interesse Social, figura como elemento, instituído pelo zoneamento, concebido por meio de Plano Diretor (ou não) que garante o direito à moradia, dependendo da modalidade, instituindo estoques de áreas da cidade para provisão de habitação de interesse social ou demarcando assentamentos precários ou favelas, a fim de garantir a permanência da população de baixa renda no local, a partir da regularização urbanística e fundiária. As modalidades de ZEIS podem ser utilizadas conjuntamente, dependendo de como foram especificadas no Plano Diretor. O Plano Diretor Estratégico de São Paulo, definiu 04 modalidades de ZEIS, que tem por objetivo a regularização urbanística e fundiária de assentamentos de baixa renda, estoque de habitação de interesse social em áreas sem e já providas de infraestrutura urbana e locais para promoção de habitação de interesse social na área de proteção à mananciais para reassentamento de famílias em situação de risco. O caso da ZEIS instituída no Jardim Edith, favela inserida no perímetro da Operação Urbana Água Espraiada é um exemplo de Zona Especial de Interesse Social 1 , demarcada em área de grande valorização imobiliária da cidade que se

\footnotetext{
${ }^{1}$ Mestranda em Arquitetura e Urbanismo, Universidade Presbiteriana Mackenzie, São Paulo, Brasil. E-mail: fernandamilitelli@gmail.com
} 


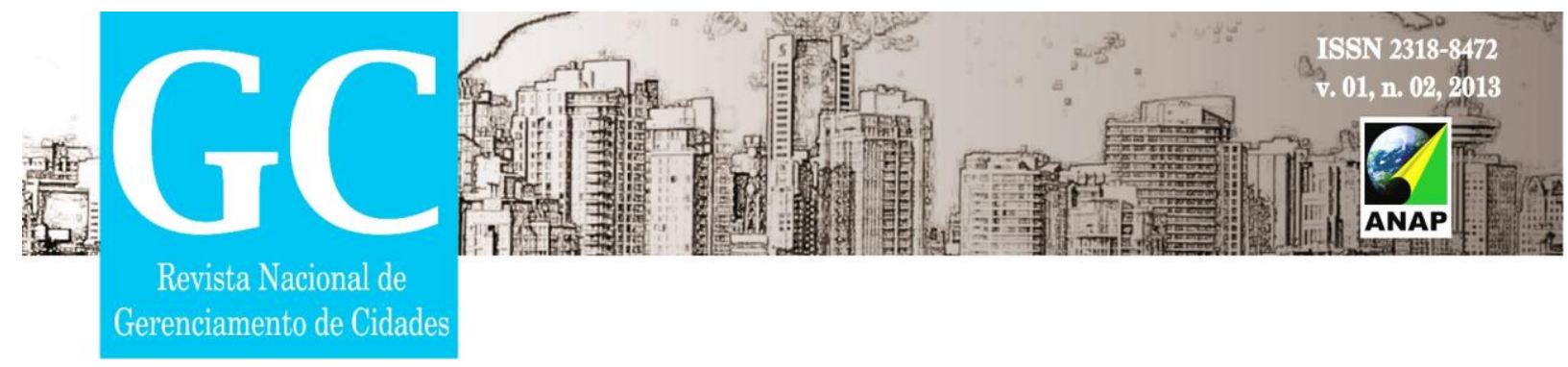

tornou um elemento de resistência, garantindo a permanência das famílias no local e culminou com o reassentamento de parte da população para um empreendimento de interesse social implantado na área antes ocupada por parte do assentamento irregular.

Palavras-chave: ZEIS. Estatuto da Cidade. Plano Diretor Estratégico de São Paulo. Operação Urbana Água Espraiada. Jardim Edith.

\section{INTRODUÇÃO}

O presente artigo tem como objetivo demonstrar a trajetória da evolução do direito urbanístico no Brasil, desde a promulgação da Constituição de 1988, que incluiu capítulos sobre a questão da função social da propriedade urbana. Posteriormente regulamentados através do Estatuto da Cidade, por meio dos instrumentos urbanísticos, base para elaboração dos Planos Diretores Municipais.

O instrumento discutido será a Zona Especial de Interesse Social (ZEIS), sua aplicação no Plano Diretor de São Paulo, exemplificada a partir da demarcação de ZEIS na Área da Operação Urbana Água Espraiada, abordado neste caso, como instrumento de resistência.

O método utilizado foi pesquisa bibliográfica, referenciada no item 8 do presente artigo. O referencial norteador, em especial, quando se trata do caso da Zona Especial de Interesse Social demarcada no perímetro da Operação Urbana Água Espraiada foi o artigo "Zonas Especiales de Interés Social (ZEIS) en ciudades brasileñas: Trayectoria reciente de implementación de un instrumento de política de suelo" desenvolvido por Raquel Rolnik e Paula Santoro, apresentado no "Foro Latinoamericano sobre instrumentos notables de intervención urbana", realizado em maio de 2013 em Quito no Equador, promovido pelo Lincoln Institute of Land Policy. 


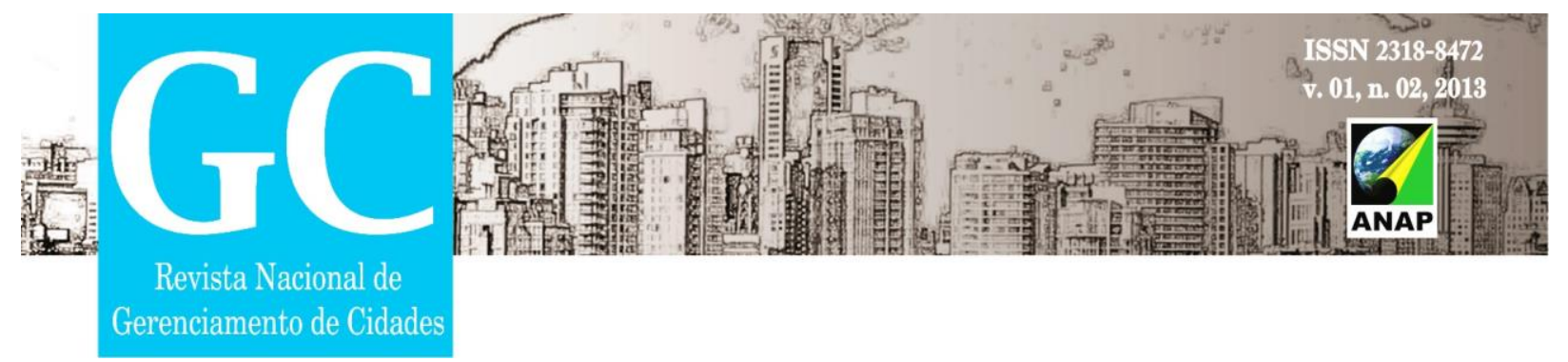

\section{NOVA ORDEM JURÍDICO URBANÍSTICA: O ESTATUTO DA CIDADE}

Com a promulgação da Constituição de 1988 e posteriormente da Lei Federal $n^{\circ} 10.257$, que instituiu o Estatuto da Cidade ${ }^{2}$, os municípios foram dotados de maior autonomia na solução de suas questões jurídicas urbanísticas através da implementação de Planos Diretores ${ }^{3}$.

Desde a década de 30, a legislação urbanística estava lentamente sendo construída de forma a materializar o principio da função social da propriedade introduzido pela Constituição Federal de $1934^{4}$.

De acordo com Alfonsin e Fernandes (2010), com a aprovação do Estatuto da Cidade a ordem jurídica e urbanística foi consolidada e necessita ser reconhecida. O Reconhecimento da autonomia do direito urbanístico não é mera questão de semântica ou retórica e sim requisito para que sejam criadas condições para efetividade da nova ordem jurídico urbanística, e especialmente para que esta nova ordem seja lida e interpretada a partir de seus próprios princípios e não reduzida pela aplicação de princípios de outros ramos do direito, especialmente ao Direito civil e ao administrativo

Saule (2001) afirma que o processo de urbanização do Brasil começou na década de 30 e teve seu auge a partir da década de 70, neste período várias constituições foram promulgadas/ outorgadas. No entanto, até o momento em que a

\footnotetext{
${ }^{2}$ Lei Federal que regulamenta o capítulo "Política urbana" da Constituição Brasileira de 1988

${ }^{3}$ De acordo com ABNT (Associação Brasileira de Normas Técnicas) o Plano diretor é o Instrumento básico de um processo de planejamento municipal para a implantação da política de desenvolvimento urbano, norteando a ação dos agentes públicos e privados.

"Seria um plano que, a partir de um diagnóstico científico da realidade física, social, econômica, política e administrativa da cidade, do município e de sua região, apresentaria um conjunto de propostas para o futuro desenvolvimento socioeconômico e futura organização espacial dos usos do solo urbano, das redes de infraestrutura e de elementos fundamentais da estrutura urbana, para a cidade e para o município, propostas estas definidas para curto, médio e longo prazos, e aprovadas por lei municipal" (VILLAÇA, 1999, p. 238), disponível em <http://urbanidades.arq.br/2008/06/o-quee-plano-diretor/>. Acesso em 25 mai. 2013

${ }^{4}$ FERNANDES, Edésio e ALFONSIN, Betânia. Coletânea de Legislação Urbanística. Belo Horizonte: Editora Fórum, Belo Horizonte - 2010
} 


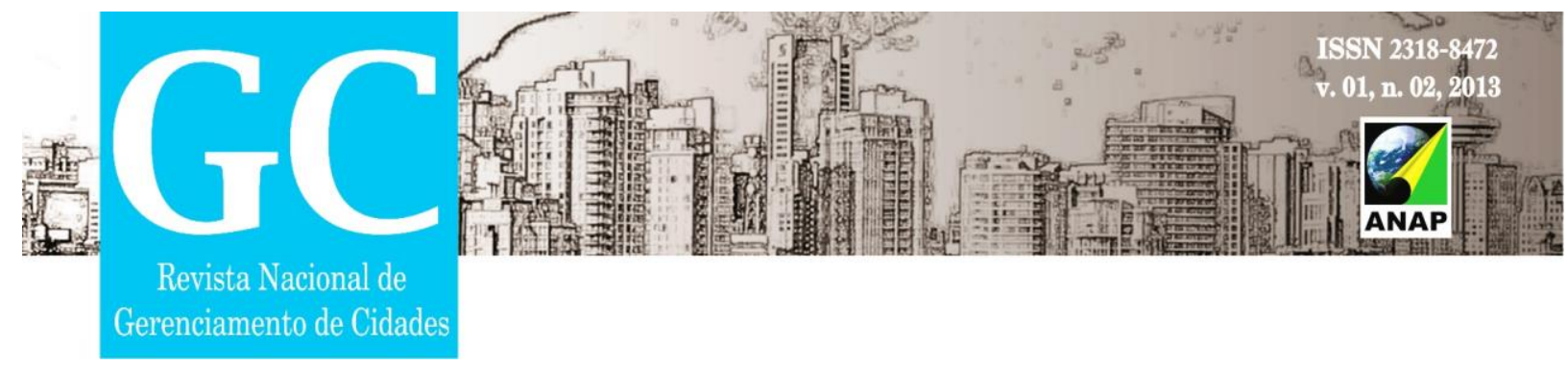

constituição de 1988 entrou em vigor não existiam dispositivos constitucionais específicos para guiar os processos de desenvolvimento territorial e para determinar as condições de gestão urbana. Grande parte do capítulo constitucional foi escrito com base na emenda popular da reforma urbana, que tinha sido formulada, discutida, disseminada e assinada por mais de 100.000 organizações sociais e indivíduos envolvidos no Movimento Nacional de Reforma Urbana. Essa Emenda propunha o reconhecimento constitucional dos seguintes princípios gerais: autonomia do governo municipal, gestão democrática das cidades, direito social à moradia, direito à regularização de assentamentos informais consolidados, função social da propriedade urbana e combate à retenção especulativa do solo urbano.

Saule (2001) ainda foca que com a promulgação da constituição de 1988, o direito de propriedade, trata do direito à propriedade e das funções sociais da cidade, deslocando as correlações para o contexto municipal mais facilmente manipuláveis. A falta de regulamentação por lei infraconstitucional do capítulo constitucional sobre política urbana gerou uma série de dificuldades jurídicas e políticas a cerca da auto aplicabilidade dos princípios e instrumentos constitucionais. Como resultados destas tensões, as organizações envolvidas no Movimento Nacional de Reforma Urbana, criaram o Fórum Nacional de Reforma Urbana, no começo da década de 90.

Segundo Rolnik (2001), o Fórum Nacional da Reforma Urbana foi o protagonista na promoção da bandeira e da agenda da reforma urbana nacionalmente e três de seus principais objetivos foram atingidos com êxito:

- Incorporação do direito social da moradia na Constituição Federal de 1988;

- Aprovação do projeto de lei federal que propunha a criação de um Fundo Nacional de Habitação de Interesse Social (FNHIS);

- Reivindicou a criação pelo governo federal de um aparato institucional adequado, no nível nacional, que promovesse o planejamento e a 


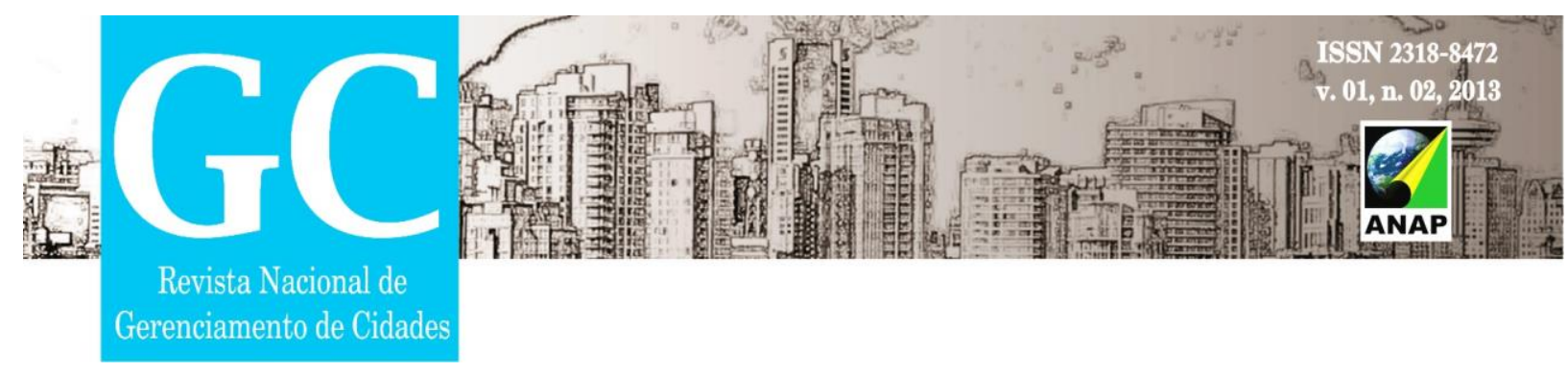

política urbana no país, o que hoje figura como Ministério das Cidades.

Alfonsin e Fernandes (2010) complementam que o Estatuto da Cidade rompeu com a longa tradição de civilismo jurídico e estabeleceu as bases de um novo paradigma jurídico-político para $\mathrm{o}$ controle do uso do solo e do desenvolvimento urbano pelo poder público e pela sociedade organizada. A Lei Federal desenvolveu de forma exemplar o princípio constitucional das funções sociais da propriedade da cidade e introduziu o conceito do direito difuso a cidades sustentáveis e criou uma série de instrumentos jurídicos urbanísticos e fiscais que podem ser usados pela administração, substituindo o paradigma individualista do Código Civil de 1916.

De acordo com Rolnik, (2001) o Estatuto da Cidade renovou e criou uma série de instrumentos jurídicos, urbanísticos e fiscais que podem ser utilizados pelas administrações municipais, especialmente no âmbito dos Planos Diretores, a fim de regulamentar induzir e reverter a ação dos mercados de terras e propriedades urbanas, de acordo com os princípios de inclusão social e sustentabilidade ambiental. Estes instrumentos podem e devem ser utilizados de maneira combinada, visando não apenas regular os processos de uso e desenvolvimento do solo, mas especialmente de induzi-los de acordo com um "projeto de cidade", expresso, sobretudo, a partir dos planos diretores.

Um destes instrumentos são as Zonas Especiais de Interesse Social. Primordialmente definidas para destinação de áreas à produção de habitação de interesse social, as Zonas Especiais de Interesse Social - ZEIS, também podem ser aplicadas a fim de demarcar uma área objeto de regularização fundiária, a fim de incorporar espaços urbanos da cidade informal, favelas, cortiços, loteamentos irregulares na Cidade Formal. 

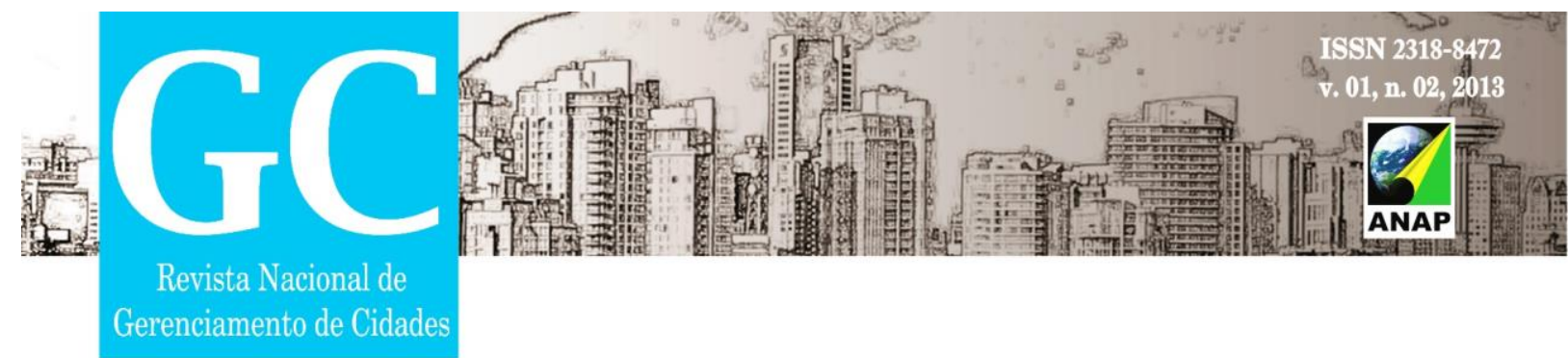

\section{ZONAS ESPECIAIS DE INTERESSE SOCIAL NO PLANO DIRETOR ESTRATÉGICO DO MUNICÍPIO DE SÃO PAULO}

As Zonas Especiais de Interesse Social ${ }^{5}$ são parcelas de áreas urbanas destinadas predominantemente à moradia de população de baixa renda e sujeitas a regras específicas de parcelamento, uso e ocupação do solo, que devem ser definidas no Plano Diretor ou em Lei Municipal Específica.

De acordo com o Estatuto da Cidade, as ZEIS podem ser classificadas em razão do tipo de ocupação que as compõe:

Terrenos públicos ou particulares ocupados por favelas, população de baixa renda ou assentamentos semelhantes, nos quais há interesse público para promoção de regularização fundiária e urbanística.

Loteamentos irregulares, nos quais o poder público tem interesse de promover a regulamentação jurídica, com implantação de infraestrutura urbana e/ou equipamentos comunitário e recuperação ambiental, permitindo desta forma eficácia da Lei 6766/79, que dispõe sobre o parcelamento urbano.

Terrenos não edificados ou subutilizados, a fim de coibir a especulação imobiliária nestas áreas, o poder público poderá, por meio do Plano Diretor, definir tais áreas como de interesse para implantação de habitação de interesse social, garantindo assim a função social da propriedade.

O Plano Diretor do Município de São Paulo, promulgado em 2002, regulamentou todos os instrumentos do Estatuto da Cidade e aprovou 964 perímetros de ZEIS, abrangendo 139,2 km² (13\% da área urbana do município).

\footnotetext{
${ }^{5}$ De acordo com o Manual de Utilização da Lei Federal 11.977- Secretaria Nacional de Habitação, Secretaria Nacional de Programas Urbanos e Ministério das Cidades.
} 


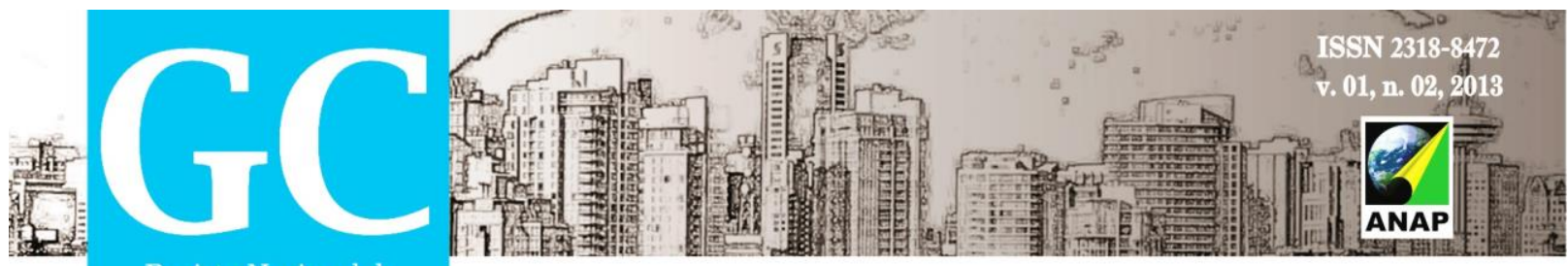

Revista Nacional de

Gerenciamento de Cidades

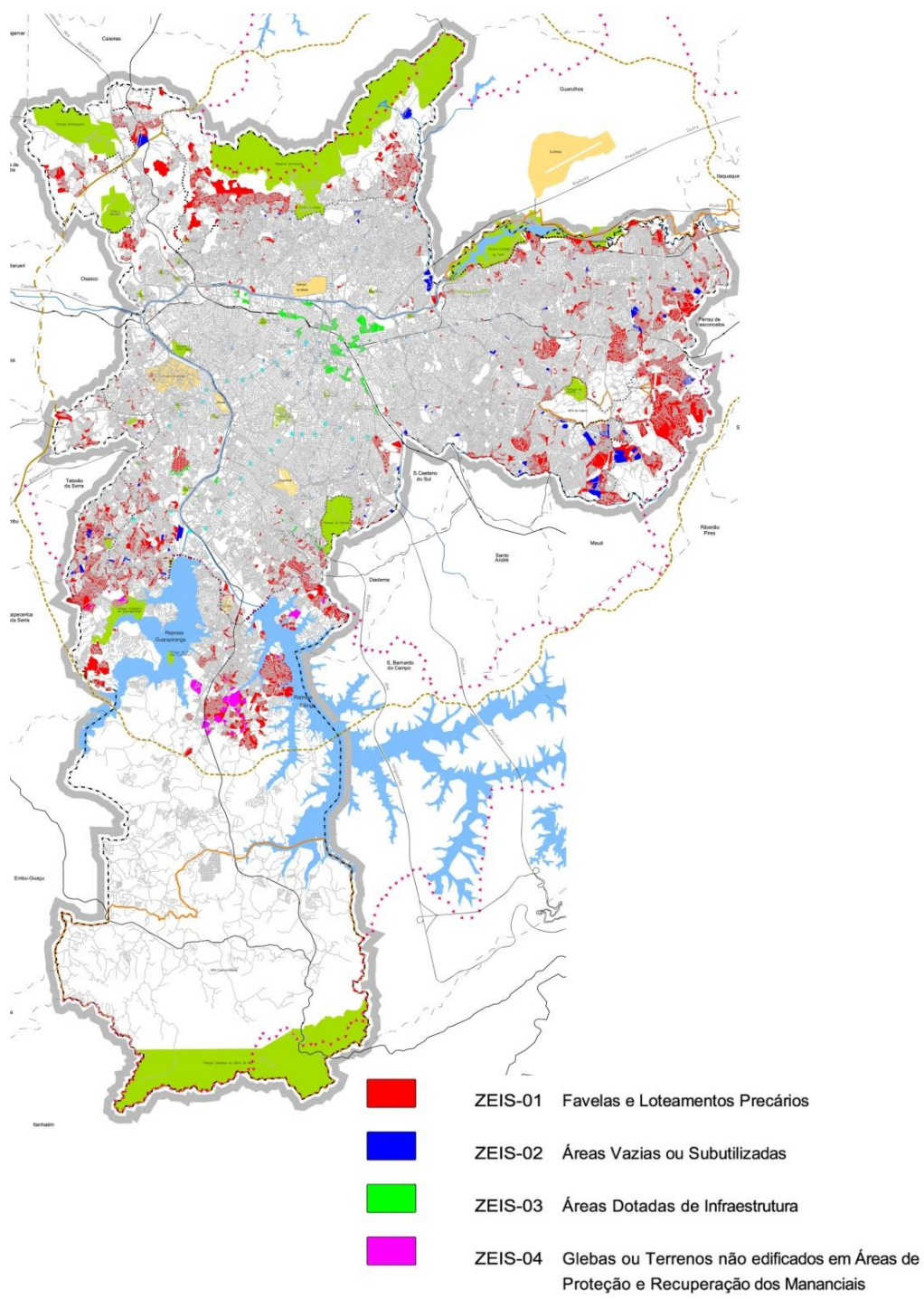

Figura 01 ${ }^{6}$ : Zonas Especiais de Interesse Social, conforme o Plano Diretor Estratégico de São Paulo, Lei Municipal n 13.430 de 13/09/2002.

De acordo com dados do Ministério das Cidades (2009) e do Plano Diretor Estratégico do Município de São Paulo (2002), a Lei Municipal $n^{\circ} 13.430$, define quatro modalidades distintas de Zonas Especiais de Interesse Social:

${ }^{6}$ Fonte:

<http://www.prefeitura.sp.gov.br/cidade/secretarias/desenvolvimento_urbano/legislacao/plano_diretor/ index.php? $p=1386>$. Acesso em: 25 mai. 2013, editorado pela autora. 


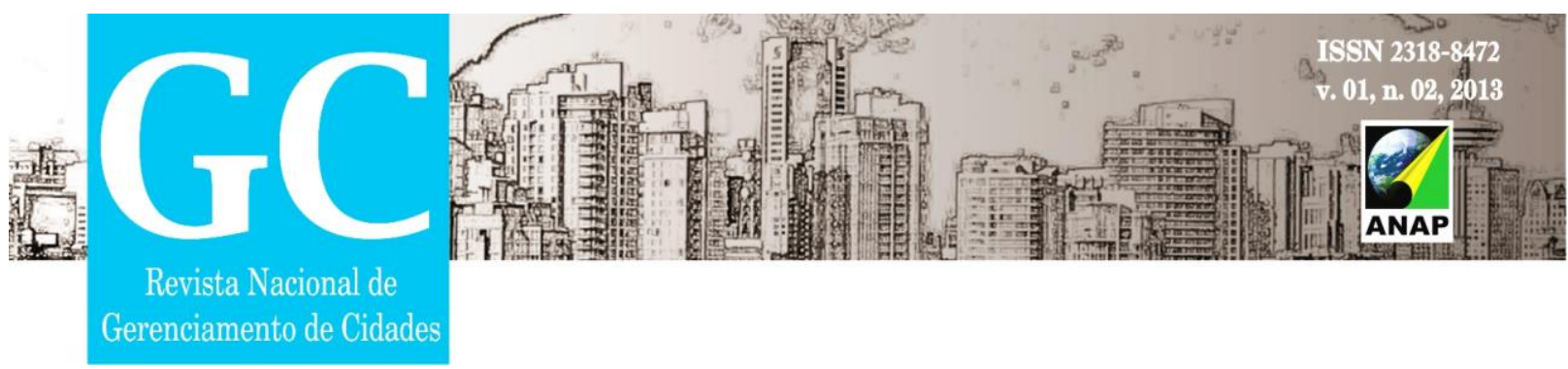

\begin{tabular}{|c|c|c|c|c|c|}
\hline ZEIS & $\begin{array}{c}\text { Percentual em Relação } \\
\text { ao total de Zonas } \\
\text { Especiais de Interesse } \\
\text { Social instituídas pela } \\
\text { Lei Municipal } \mathrm{n}^{\circ} \\
\text { 13.430(dados: } \\
\text { Ministério das Cidades } \\
\text { 2009) }\end{array}$ & $\begin{array}{c}\text { Caracterização } \\
\text { da Área } \\
\text { demarcada }\end{array}$ & $\begin{array}{c}\text { Caracterização da } \\
\text { Ocupação (Conforme Artigo } \\
171 \text { da Lei Municipal no } \\
13.430 \text { ) }\end{array}$ & Objetivo & Especificações \\
\hline 1 & $85 \%$ & Áreas Ocupadas & $\begin{array}{c}\text { Áreas ocupadas por } \\
\text { população de baixa renda, } \\
\text { abrangendo favelas, } \\
\text { loteamentos precários e } \\
\text { empreendimentos } \\
\text { habitacionais de interesse } \\
\text { social ou do mercado popular }\end{array}$ & $\begin{array}{l}\text { Regularização } \\
\text { Urbanística e } \\
\text { Fundiária }\end{array}$ & $\begin{array}{l}\text { Recuperação urbanística, a } \\
\text { regularização fundiária, a produção } \\
\text { e manutenção de Habitações de } \\
\text { Interesse Social - HIS }\end{array}$ \\
\hline 2 & $6 \%$ & $\begin{array}{c}\text { Áreas Vazias ou } \\
\text { subutilizadas }\end{array}$ & $\begin{array}{l}\text { Áreas com predominância de } \\
\text { glebas ou terrenos não } \\
\text { edificados ou subutilizados, } \\
\text { adequados à urbanização. }\end{array}$ & $\begin{array}{l}\text { Promoção de } \\
\text { Unidades } \\
\text { Habitacionais }\end{array}$ & $\begin{array}{l}\text { Promoção de Habitação de } \\
\text { Interesse Social - HIS ou do } \\
\text { Mercado Popular - HMP }\end{array}$ \\
\hline 3 & $5 \%$ & $\begin{array}{c}\text { Áreas } \\
\text { subutilizadas em } \\
\text { regiões dotadas } \\
\text { de infraestrutura }\end{array}$ & $\begin{array}{l}\text { Áreas com predominância de } \\
\text { terrenos ou edificações } \\
\text { subutilizados situados em } \\
\text { áreas dotadas de } \\
\text { infraestrutura, serviços } \\
\text { urbanos e oferta de } \\
\text { empregos, ou que estejam } \\
\text { recebendo investimentos } \\
\text { desta natureza }\end{array}$ & $\begin{array}{l}\text { Promoção e } \\
\text { ampliação de uso } \\
\text { habitacional de } \\
\text { interesse social }\end{array}$ & $\begin{array}{c}\text { Promover ou ampliar o uso por } \\
\text { Habitação de Interesse Social - HIS } \\
\text { ou do Mercado Popular - HMP, e } \\
\text { melhorar as condiç̃os habitacionais } \\
\text { da população moradora }\end{array}$ \\
\hline 4 & $3 \%$ & $\begin{array}{l}\text { Áreas vazias } \\
\text { localizadas na } \\
\text { zona de proteção } \\
\text { aos mananciais }\end{array}$ & $\begin{array}{l}\text { Glebas ou terrenos não } \\
\text { edificados e adequados à } \\
\text { urbanização, localizados em } \\
\text { áreas de proteção aos } \\
\text { mananciais, ou de proteção } \\
\text { ambiental, }\end{array}$ & $\begin{array}{c}\text { Promoção de } \\
\text { Habitação de } \\
\text { Interesse Social } \\
\text { para reassentar } \\
\text { famílias } \\
\text { localizadas em } \\
\text { áreas de risco }\end{array}$ & $\begin{array}{c}\text { Destinados a projetos de Habitação } \\
\text { de Interesse Social promovidos pelo } \\
\text { Poder Público, com controle } \\
\text { ambiental, para o atendimento } \\
\text { habitacional de famílias removidas } \\
\text { de áreas de risco e de preservação } \\
\text { permanente, ou ao } \\
\text { desadensamento de assentamentos } \\
\text { populares definidos como ZEIS } 1\end{array}$ \\
\hline
\end{tabular}

Quadro 01': Zonas Especiais de Interesse Social, conforme artigo 171 do Plano Diretor Estratégico de São Paulo, Lei Municipal n 13.430 de 13/09/2002. Elaborado pela autora

A análise do Ministério das Cidades (2009) complementa ainda que as ZEIS 1 e 2 foram regulamentadas permitindo o uso comercial e de serviços em âmbito local com densidade habitacional média alta, identificada a partir do coeficiente de aproveitamento destas zonas que é 2,5.

${ }^{7}$ Fonte: Lei Municipal de São Paulo n० 13.430 e Como delimitar e regulamentar Zonas Especiais de Interesse Social: ZEIS de Vazios Urbanos - Ministério das Cidades 2009 


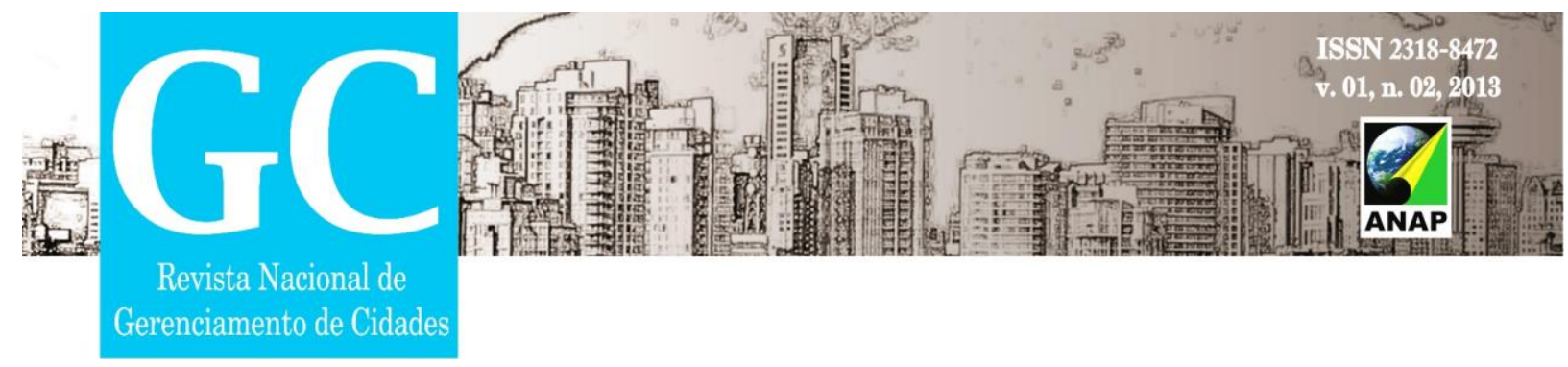

As ZEIS 3 permanecem com o caráter de ocupação misto e densidades maiores que as de seu entorno, prevendo o coeficiente de aproveitamento de 4. Nas ZEIS 4, a densidade estipulada é baixa, verificada a partir de seu coeficiente de aproveitamento máximo, 1.

A análise do quadro 1 demonstra que a maior parte das Zonas Especiais de Interesse Sociais instituídas pelo Plano Diretor Estratégico de São Paulo está vinculada á áreas já ocupadas por loteamentos irregulares e favelas. Priorizam a regularização urbanística e fundiária destes assentamentos, com objetivo de reconhecer estas áreas da cidade, dotando-as de infraestrutura garantindo juridicamente a manutenção da população no local.

As ZEIS têm sido largamente utilizadas como instrumento de reconhecimento da posse, garantia do direito à moradia, evitando remoções forçadas, muitas vezes violentas. Alguns municípios têm gravado ZEIS de vazios próximas a ZEIS de áreas ocupadas irregularmente de forma a articular necessidades habitacionais com oportunidades (terras subutilizadas) e viabilizar, em muitos casos, a o reassentamento de famílias, na mesma região, em função de obras de urbanização nos assentamentos.(ROLNIK e SANTORO, 2013, p.9)

O emblemático exemplo do Jardim Edith, favela localizada no perímetro da Operação Urbana Águas Espraiadas, explanado adiante exemplificará, em parte, a aplicação deste instrumento como elemento de resistência.

\section{ZONA ESPECIAL DE INTERESSE SOCIAL COMO INSTRUMENTO DE RESISTÊNCIA: O EXEMPLO DA OPERAÇÃO URBANA CONSOCIADA ÁGUA ESPRAIADA}




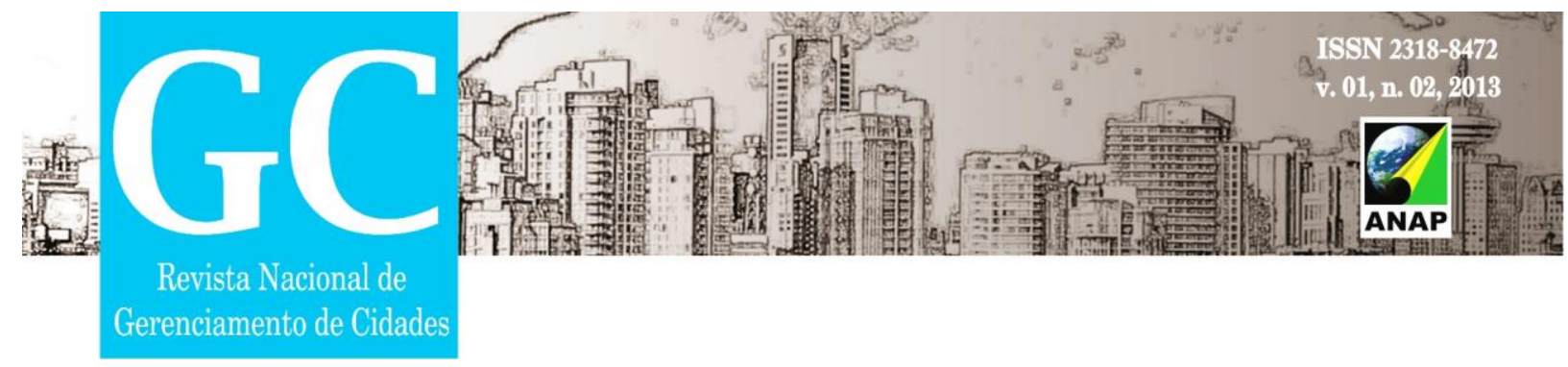

De acordo com dados da Prefeitura Municipal de São Paulo (PMSP) $)^{8}$, a Operação Urbana Consorciada ${ }^{9}$ Água Espraiada, instituída pela Lei Municipal $n^{\circ}$ 13.260/2001, alterada pela Lei Municipal 15.416/2011, foi a primeira operação urbana aprovada pós Estatuto da Cidade. O perímetro da Operação concerne uma área de $3.750 .000 \mathrm{~m}^{2}$, subdividida em seis setores: Brooklin, Berrini, Marginal Pinheiros, Chucri Zaidan, Jabaquara e Americanópolis, integrantes do perímetro das subprefeituras de Pinheiros e Santo Amaro.

8

<http://www.prefeitura.sp.gov.br/cidade/secretarias/desenvolvimento_urbano/sp_urbanismo/operacoe s_urbanas/agua_espraiada/>. Acesso em: 25 mai. 2013

9 "Operações Ürbanas Consorciadas constituem um tipo de intervenção urbanística voltada para transformação estrutural de um setor da cidade. As operações envolvem simultaneamente: 0 redesenho deste setor (tanto de seu espaço público como privado); a combinação de investimentos privados e públicos para sua execução e a alteração, manejo e transação dos direitos de uso e edificabilidade do solo e obrigações de urbanização. Trata-se portanto de um instrumento de implementação de um projeto urbano ( e não apenas da atividade de controle urbano) para uma determinada área da cidade, implantado por meio de parceria entre proprietários, poder público, investidores privados moradores e usuários permanentes." (ROLNIK, et al, 2001, p. 80) 


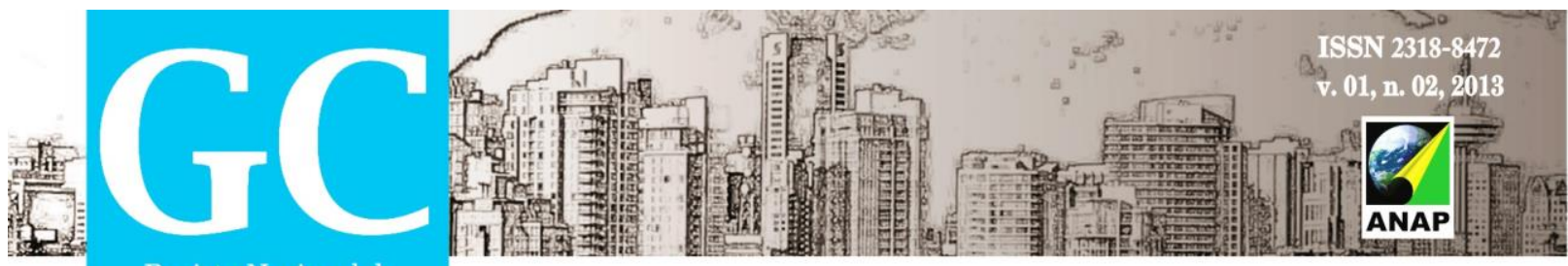

Revista Nacional de

Gerenciamento de Cidades

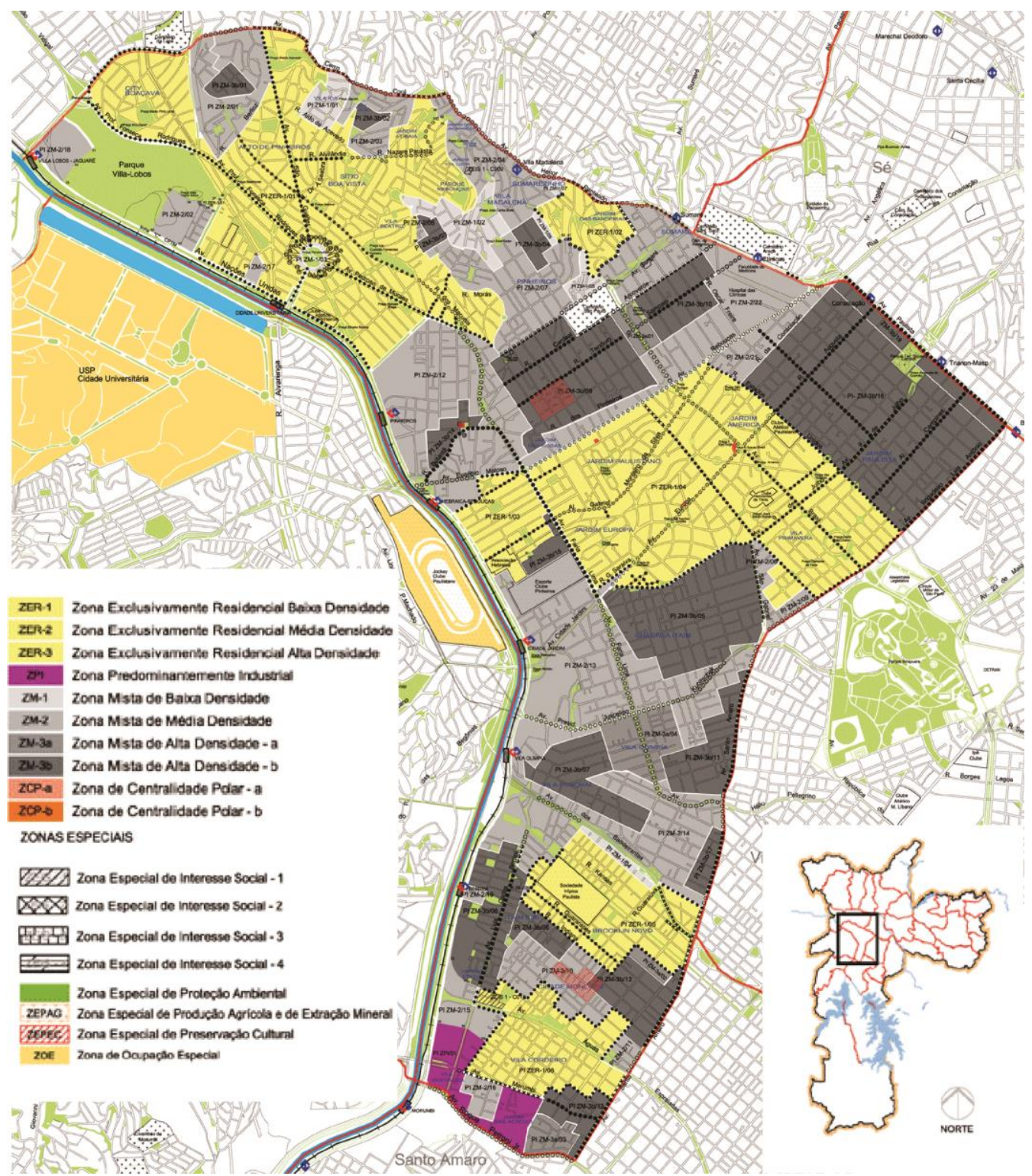

Figura $0^{10}$ : Zoneamento da Subprefeitura de Pinheiros, conforme o Plano Diretor Estratégico Regional de São Paulo.

O Jardim Edith, exemplo que será abordado como Zona Especial de Interesse Social como elemento de resistência está inserido no perímetro da Operação Urbana Consorciada Água Espraiada na porção administrativa da

\footnotetext{
${ }^{10}$ Fonte:

<http://www.prefeitura.sp.gov.br/cidade/secretarias/desenvolvimento_urbano/legislacao/planos_regio nais/index.php? $\mathrm{p}=1891>$. Acesso em: 25 mai. 2013 , editorado pela autora.
} 


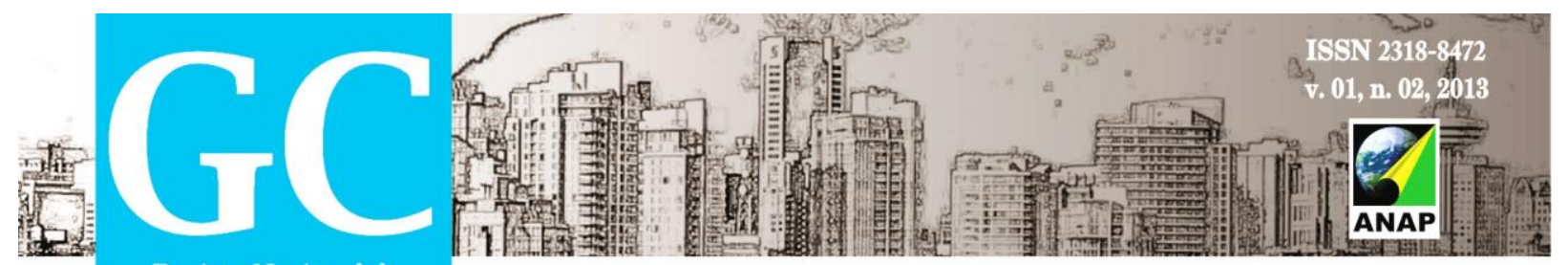

Revista Nacional de

Gerenciamento de Cidades

subprefeitura de Pinheiros. De acordo como o Plano Estratégico Regional de Pinheiros, a área do Jardim Edith está grafada como Zona Especial de Interesse Social 1, definida como ZEIS 01 - CO1 ${ }^{11}$.

O Jardim Edith, composto 8.500 famílias distribuídas em 68 favelas localizadas às margens do córrego Água Espraiada, foi em parte removido entre 1993 e 1996, para implantação de empresas na região. Do universo de remoções, $20 \%$ das famílias foram reassentadas em conjuntos habitacionais de interesse social, destas $15 \%$ foram relocadas no bairro do Jaguaré à 10 quilômetros do local e $5 \%$ na zona leste do município, cerca 30 quilômetros do local. As famílias não reassentadas,receberam indenização e migraram para outras favelas, na região sul do município. (FIX, 2007, p. 98-101; FIX, 2001 apud Rolnik e Santoro, 2013 p. 11).

\footnotetext{
${ }^{11}$ Subseção II - Das Zonas Especiais de Interesse Social - ZEIS

Art. 74: Os perímetros das ZEIS são os constantes do Quadro 04B e delimitados do Mapa 04 integrantes deste livro

Paragrafo Único: No caso de atendimento por provisão habitacional de todas as famílias das ZEIS 01 - CO11, poderá ser alterado o zoneamento definido para área demarcada, na revisão do Plano Diretor de 2006, visando modificar suas características de aproveitamento, uso e ocupação.
} 

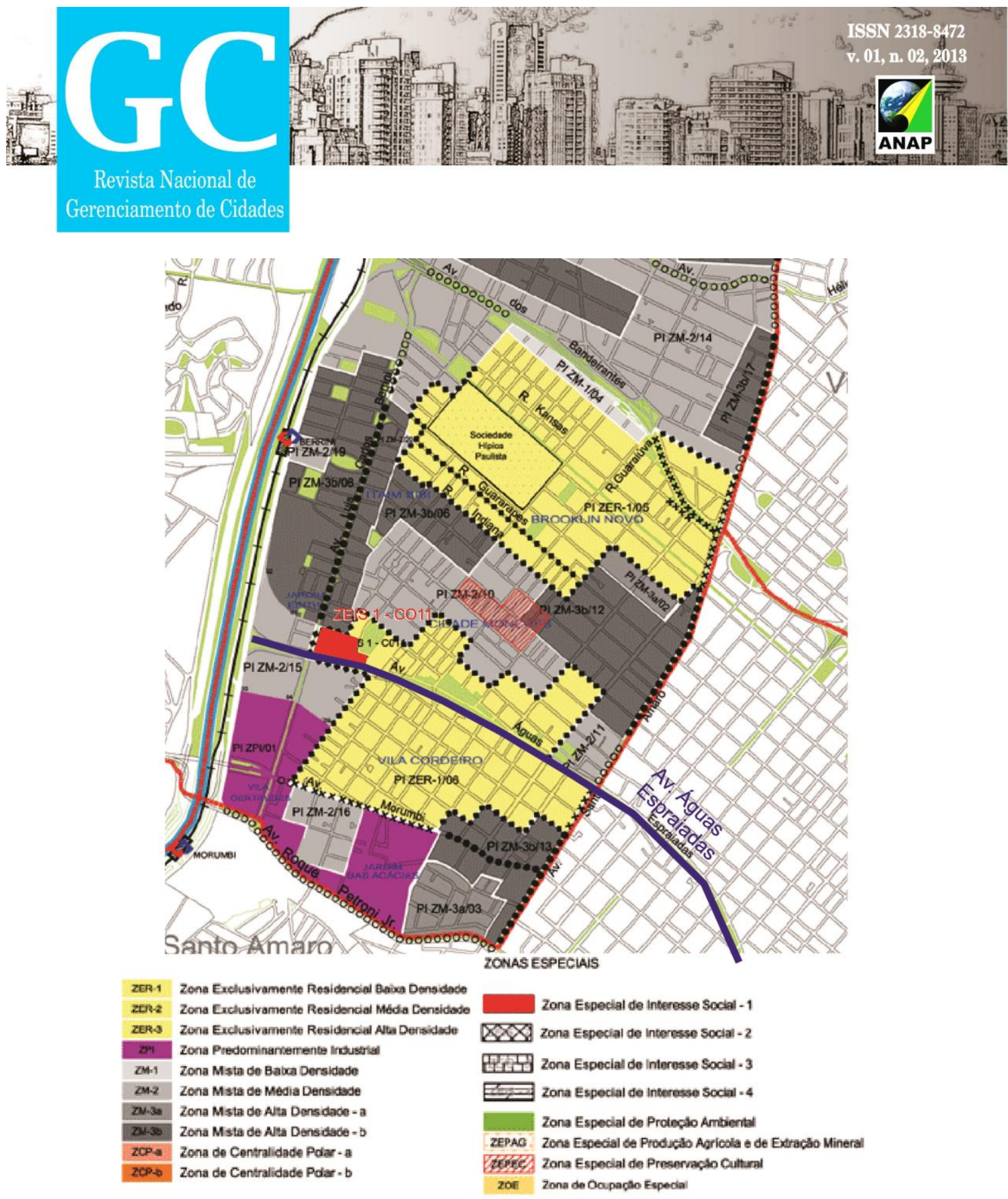

Figura $03^{12}$ : Zoneamento da Subprefeitura de Pinheiros, conforme o Plano Diretor Estratégico Regional de São Paulo.

\footnotetext{
${ }^{12}$ Fonte:
}

<http://www.prefeitura.sp.gov.br/cidade/secretarias/desenvolvimento_urbano/legislacao/planos_regio nais/index.php?p=1891>. Acesso em: 25 mai. 2013 , editorado e formatado pela autora. 


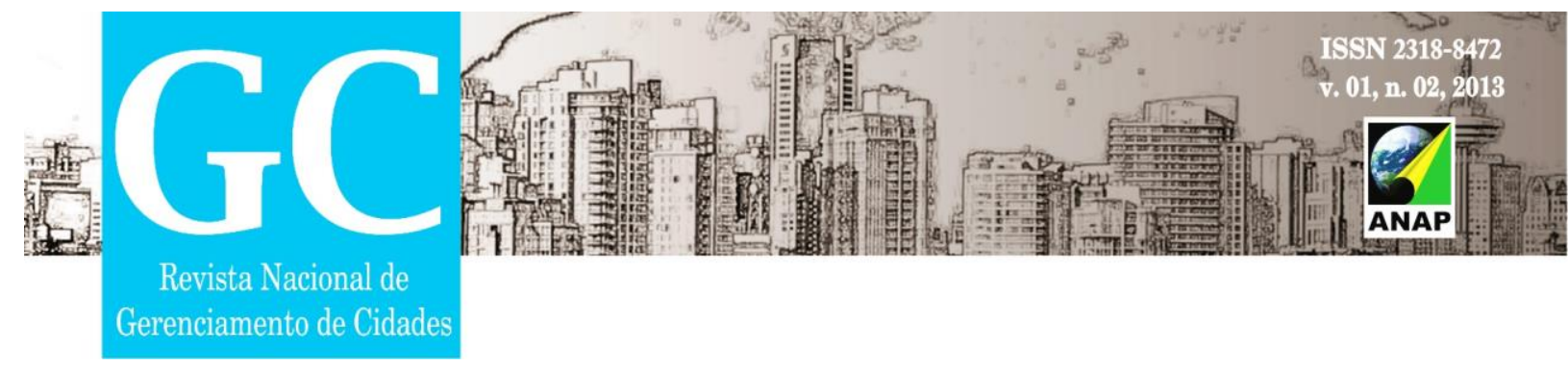

Conforme apontado por Rolnik e Santoro (2013), no início de 2001 foram articuladas novas tentativas de remoção das famílias que ainda permaneciam na área, em virtude da implantação ode obras viárias pelo DER. "Neste contexto a inserção das áreas remanescentes de favelas como ZEIS na Lei da Operação Urbana no final de 2002 foi considerada pelos moradores uma grande vitória". (ROLNIK e SANTORO, 2013, p.11).

Apesar dos percalços, a inclusão da área remanescente do Jardim Edith em Zona Especial de Interesse Social, inserida no perímetro da Operação Urbana Consorciada Água Espraiada, garantiu as famílias o direito de permanência no local, demostrando a amplitude das ZEIS como elemento de resistência e reconhecimento de direitos. "Neste caso as ZEIS não apenas afirmaram uma localização já existente como determinaram um caráter mais includente da operação" (ROLNIK e SANTORO, 2013, p.11)

De acordo com Romeiro (2010), este caso é emblemático, uma vez que uma Ação Civil Pública movida pelo Ministério Público, Defensoria Pública e população organizada evitou que a favela fosse removida, obtendo um acordo provisório que obrigou a prefeitura a realizar um empreendimento de HIS (Romero, 2010, p. 77). A decisão judicial que ordenou a construção das habitações no local valeu-se da justificativa de tratar-se de uma ZEIS". (ROLNIK e SANTORO, 2013, p.11)

O empreendimento de Habitação de interesse social construído para abrigar as famílias remanescentes do Jardim Edith conta com 250 unidades habitacionais, de acordo com Rolnik e Santoro (2013), outras 817 unidades estão em construção em outros pontos do perímetro da Operação Urbana Água Espraiada.

O Conjunto Habitacional Jardim Edith está localizado na mesma área onde estava inserida parte do remanescente da favela (ZEIS 01 - C011 - Figura 03). Concebido pelo escritório de arquitetura MMBB, apresenta $27.700 \mathrm{~m}^{2}$ de área construída, 250 unidades habitacionais com $50 \mathrm{~m}^{2}$ cada além de equipamentos como restaurante escola, unidade básica de saúde e creche. Tais equipamentos 


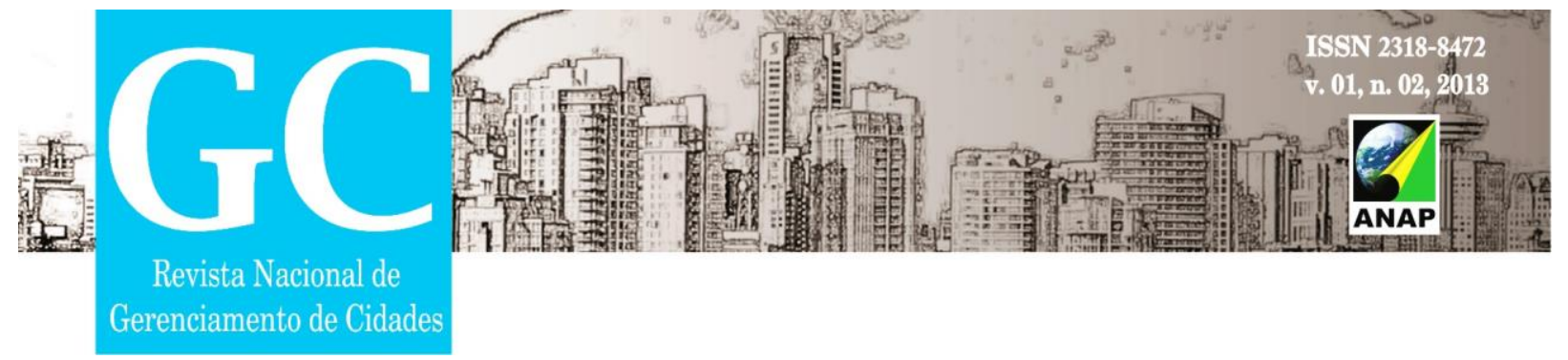

foram desenvolvidos para atender a demanda dos moradores do conjunto quanto e do público das grandes empresas próximas ao local, com intenção de inserção do conjunto na economia e no cotidiano da região ${ }^{13}$.

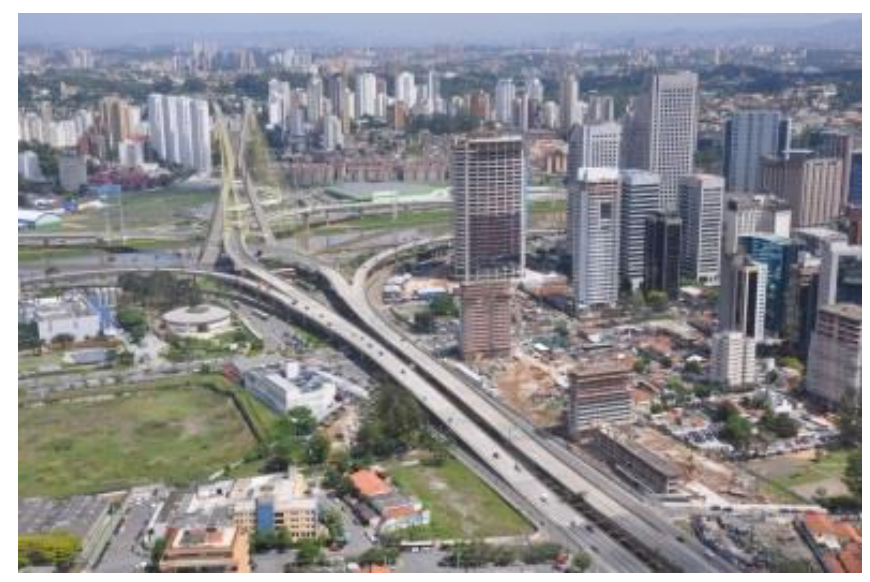

Figura $04^{14}$ : Localização do Conjunto Habitacional Jardim Edith - Projeto MMBB

De acordo com dados do $\mathrm{MMBB}^{15}$, para garantir a integração urbana do empreendimento de interesse social com o entorno, área extremamente valorizada da cidade, o projeto articulou a verticalização do programa de moradia a um embasamento constituído por equipamentos públicos (restaurante escola, UBS, creche), interligando todos os edifícios habitacionais, conferindo "à convivência dos moradores uma adequada reserva em meio à escala metropolitana da área circundante"(MMBB, 2011).
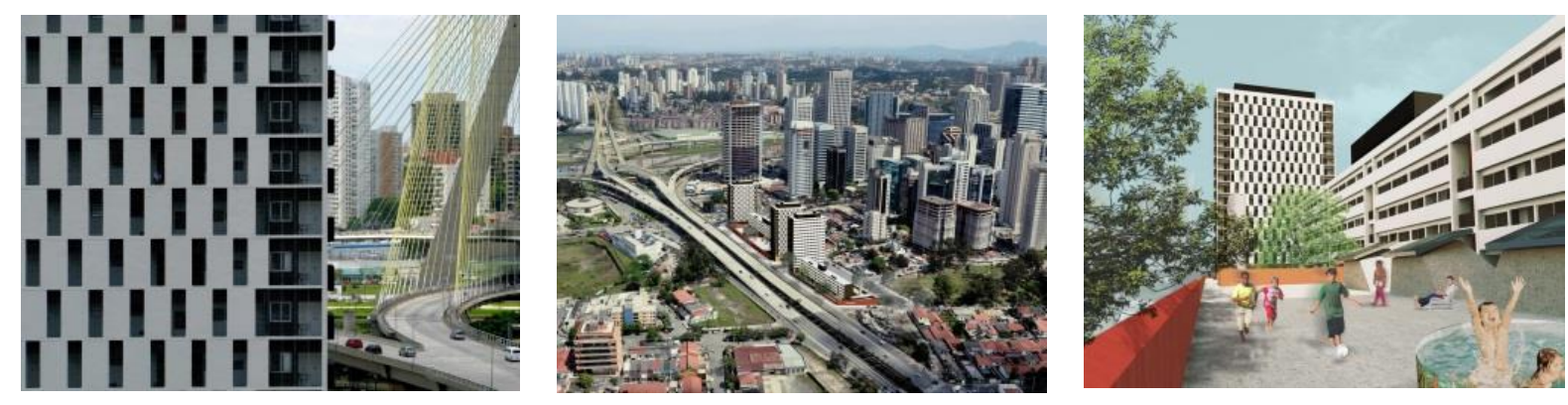

\footnotetext{
${ }^{13}<$ http://www.mmbb.com.br/projects/details/74/4>. Acesso em : 26 mai. 2013

${ }^{14}$ Fonte: <http://www.mmbb.com.br/projects/fullscreen/74/3/1642> Acesso em: 26 mai. 2013

${ }^{15}$ Fonte:< http://www.mmbb.com.br/projects/details/74/4>. Acesso em: 26 mai. 2013
} 


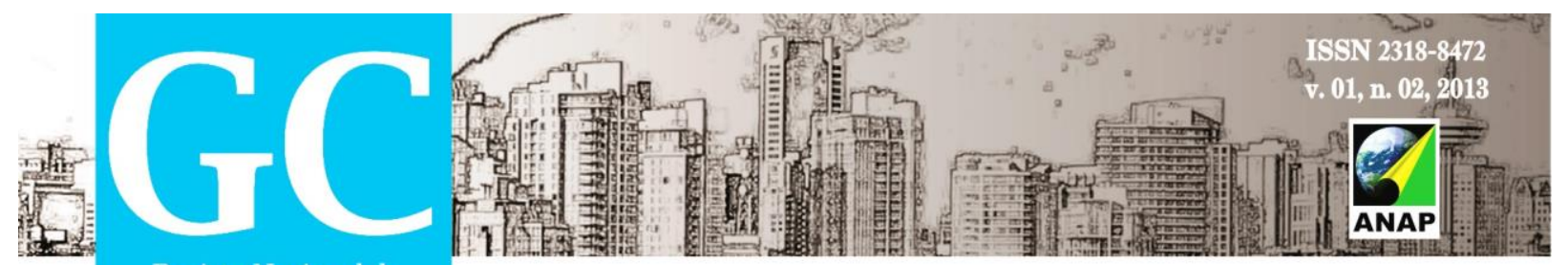

Revista Nacional de

Gerenciamento de Cidades

Figuras 05, 06 e $7^{16}$ : Respectivamente: Detalhe das fachadas com entorne, maquete eletrônica da implantação do projeto e maquete eletrônica do embasamento das torres habitacionais

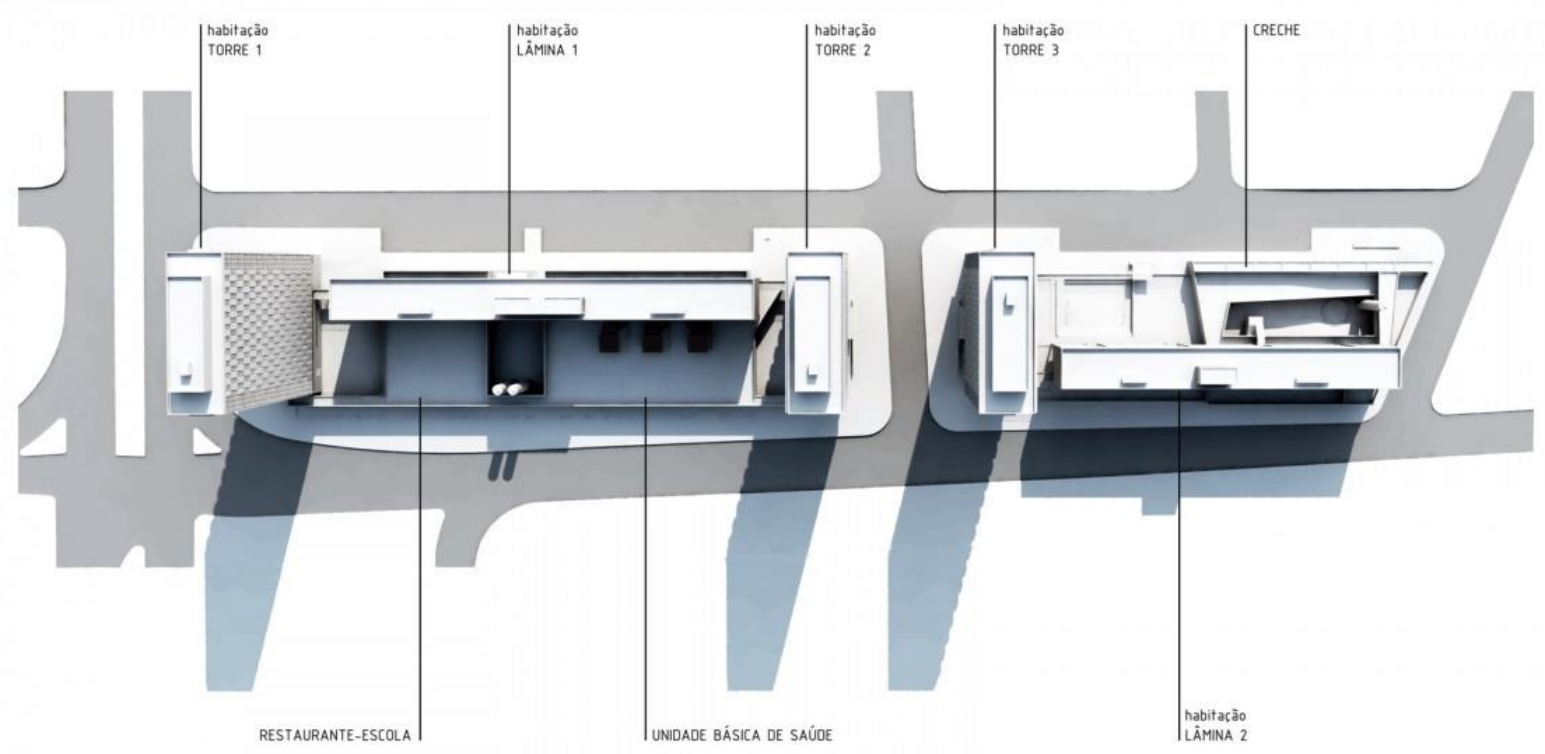

Figura $08^{17}$ : Modelo Eletrônico volumétrico do Conjunto Habitacional Jardim Edith

\section{CONSIDERAÇÕES FINAIS}

O caso do Conjunto Habitacional Jardim Edith reflete a trajetória da legislação urbanística Brasileira, desde a Constituição de 1988, com a promulgação do Estatuto da Cidade na promoção de instrumentos urbanísticos que garantam a função social da propriedade e da cidade, expresso, neste caso através do zoneamento aplicado em decorrência do Plano Diretor.

16 Fonte: Respectivamente: <http://www.mmbb.com.br/projects/fullscreen/74/3/1716>;< http://www.mmbb.com.br/projects/fullscreen/74/17/1667>

<http://www.mmbb.com.br/projects/fullscreen/74/17/1624>. Acesso em: 26 mai. 2013

${ }^{17}$ Fonte:< http://www.mmbb.com.br/projects/fullscreen/74/17/1627>. Acesso em: 26 mai. 2013 


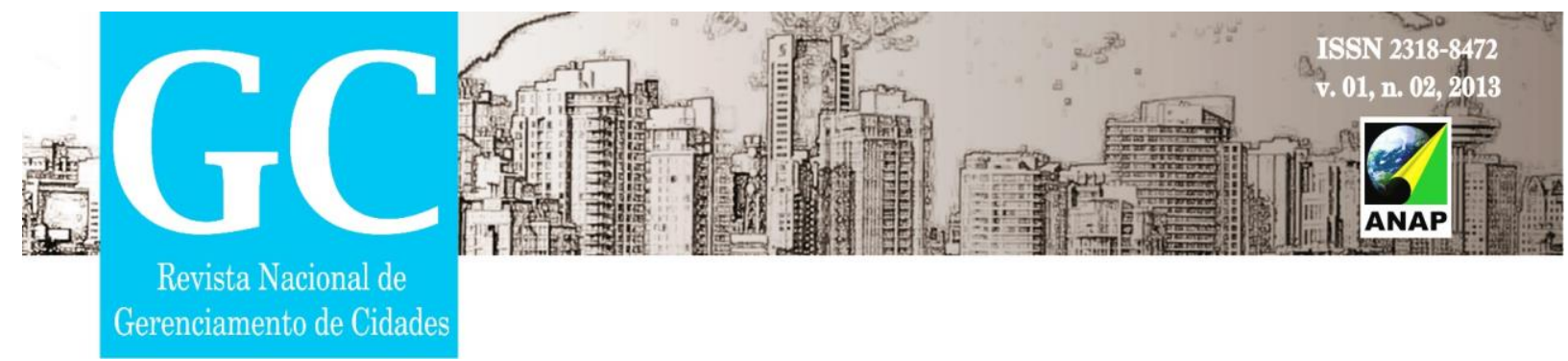

Conforme Rolnik e Santoro (2013), o caso apontado reflete a utilização de um instrumento urbanístico com finalidade de miscigenação de grupos sociais no espaço urbano, evitando a expulsão de população de baixa renda de locais valorizados pelo mercado imobiliário, utilizada como outra modalidade do inclusionary zoning.

As ZEIS poderiam ser consideradas, embora com diferenças, como uma forma específica de inclusionary zoning (zoneamento includente), termo se refere a programas, normas ou leis que exigem ou estimulam empreendedores privados a ofertarem habitação de interesse social em seus empreendimentos. (ROLNIK e SANTORO, 2013, p.6)

Entretanto, deve ser considerado que incialmente o Jardim Edith era composto por 8.500 famílias, o atendimento habitacional para as famílias no perímetro da operação urbana corresponde a $1.067{ }^{18}$ unidades, apenas $12,55 \%$ do total de famílias residentes na área de intervenção

Os dados acima demostram apesar da legislação urbanística oferecer subsídios suficientes para inclusão social, garantia da função social da propriedade e do direito de moradia digna, a efetivação plena destes direitos remete a entraves judiciais e conflitos de interesses junto ao mercado imobiliário, quando se trata da permanecia de população de baixa renda em áreas valorizadas da cidade.

A produção de novas moradias em áreas valorizadas, objeto de conflitos de interesses fundiários, situações nas quais o instrumento das ZEIS foi utilizado para evitar que a população fosse transferida para outras áreas, menos valorizadas. (ROLNIK e SANTORO, 2013, p.21)

\section{REFERÊNCIAS}

\footnotetext{
${ }^{18}$ Corresponde a somatória de 250 com 817 unidades habitacionais
} 


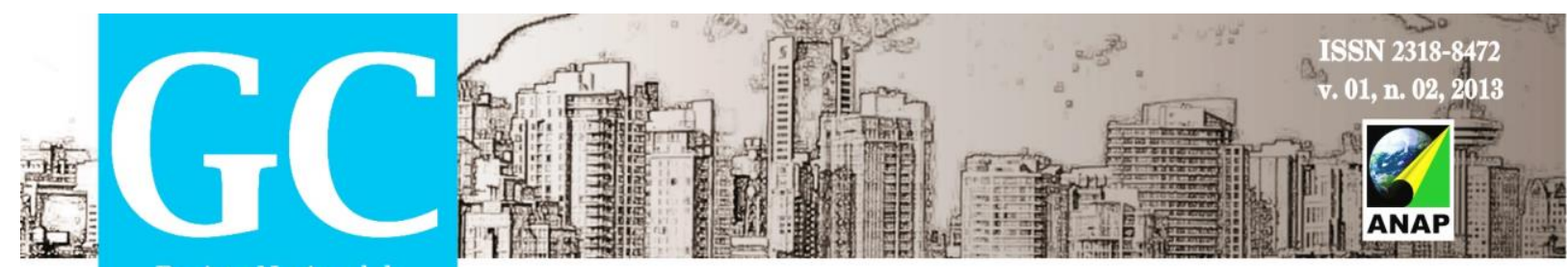

Revista Nacional de

Gerenciamento de Cidades

ALFONSIN, B. e FERNANDES, E.. Coletânea de Legislação Urbanística. Belo Horizonte: Editora Fórum, 2010

BRASIL. Ministério das Cidades. Como delimitar e regulamentar Zonas Especiais de Interesse Social: ZEIS de Vazios Urbanos. Brasília, DF, 2009. 50p

.Regularização Fundiária Urbana: Como aplicar a Lei Federal no 11.977/2009. Brasília, DF, 2010. 40p

BRASIL. Constituição (1988). Capítulo II: da Política Urbana. Disponível em:

<http://www.planalto.gov.br/ccivil_03/constituicao/constituicaocompilado.htm>. Acesso em: 26 mai. 2013

BRASIL. Lei Federal n 10. 257, de 10 de julho de 2001. Regulamenta os arts. 182 e 183 da Constituição Federal, estabelece diretrizes gerais da política urbana e dá outras providências. Disponível em: <http://www.planalto.gov.br/ccivil_03/leis/leis_2001//10257.htm>. Acesso em: 26 mai. 2013

MELLO, F.F. , MOREIRA, M., BRAGA, M. MMBB Arquitetura. Projetos: Jardim Edith, 2011. Disponível em: < http://www.mmbb.com.br/projects/fullscreen/74/17/1627>. Acesso em: 26 mai. 2013

. MMBB Arquitetura. Projetos: Jardim Edith, 2011. Disponível em: <http://www.mmbb.com.br/projects/fullscreen/74/3/1642> Acesso em: 26 mai. 2013

MMBB Arquitetura. Projetos: Jardim Edith, 2011. Disponível em: <http://www.mmbb.com.br/projects/details/74/4>. Acesso em: 26 mai. 2013 MMBB Arquitetura. Projetos: Jardim Edith, 2011. Disponível em: <http://www.mmbb.com.br/projects/fullscreen/74/3/1716>. Acesso em: 26 mai. 2013 MMBB Arquitetura. Projetos: Jardim Edith, 2011. Disponível em: <http://www.mmbb.com.br/projects/fullscreen/74/17/1667>. Acesso em: 26 mai. 2013 MMBB Arquitetura. Projetos: Jardim Edith, 2011. Disponível em: <http://www.mmbb.com.br/projects/fullscreen/74/17/1624>. Acesso em: 26 mai. 2013 


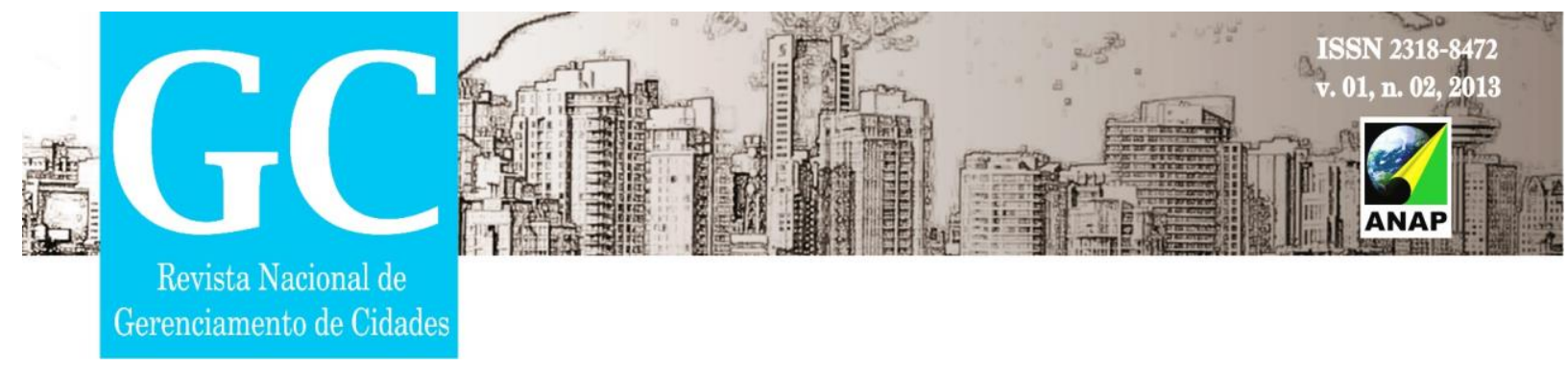

MMBB Arquitetura. Projetos: Jardim Edith, 2011. Disponível em:

<http://www.mmbb.com.br/projects/details/74/4>. Acesso em : 26 mai. 2013

MILITELLI, F.A. Regularização Fundiária: A aplicação dos Instrumentos Urbanísticos Previstos no Plano Diretor Estratégico de São Paulo. 2011. 43f. Trabalho de Conclusão de Curso

(Especialização). Faculdade de Direito, Pontifícia Universidade Católica de Minas Gerais, 2011.

ROLNIK, R. e SAULE, N. (org.). Estatuto da Cidade: Guia para Implementação pelos municípios e cidadãos. Brasília, DF, 2001.

ROLNIK, R. e SANTORO, P. Zonas Especiales de Interés Social (ZEIS) en ciudades brasileñas: Trayectoria reciente de implementación de un instrumento de política de suelo. In FORO LATINOAMERICANO SOBRE INSTRUMENTOS NOTABLES DE INTERVENCIÓN URBANA. 2013, Quito. Anais. Quito: Lincoln Institute of Land Policy, 2013. CD- ROM

SÃO PAULO (Município). Lei n 13.430, de 13 de setembro de 2002. Dispõe sobre o Plano Diretor Estratégico de São Paulo. Disponível em:

<http://www.prefeitura.sp.gov.br/cidade/secretarias/desenvolvimento_urbano/legislacao/plano_diretor/ index.php? $p=1386>$. Acesso em: 25 mai. 2013

VILLAÇA, F. O processo de urbanização no Brasil, 1999. Disponível em:

<http://urbanidades.arq.br/2008/06/o-que-e-plano-diretor/>. Acesso em 25 mai. 2013

$<$ http://www.prefeitura.sp.gov.br/cidade/secretarias/desenvolvimento_urbano/legislacao/planos_regio nais/index.php? $\mathrm{p}=1891>$. Acesso em: 25 mai. 2013

$<$ http://www.prefeitura.sp.gov.br/cidade/secretarias/desenvolvimento_urbano/sp_urbanismo/operacoe s_urbanas/agua_espraiada/>. Acesso em: 25 mai. 2013

<http://www.prefeitura.sp.gov.br/cidade/secretarias/desenvolvimento_urbano/legislacao/planos_regio nais/index.php?p=1891>. Acesso em: 25 mai. 2013 